\title{
Ethical, professional, and legal obligations in clinical practice: a series of discussion topics for postgraduate medical education
}

\section{Topic 5: disclosing confidential information}

\author{
D M Gore
}

This is the last discussion topic in a series of five dealing with ethical, professional, and legal obligations of clinical practice. Funior doctors tend to lack confidence in these subjects, and thus I organised a series of informal discussions in our surgical unit on which these discussion articles are based. The sessions were prepared with reference to nonacademic literature readily available from the General Medical Council and the medical defence organisations. While our unit dealt with these issues from a surgical perspective, the obligations of clinical practice apply to all practitioners and the series could be easily modified for other clinical specialties.

Sometimes the principle of confidentiality conflicts with ethical, professional, and legal obligations.

\section{Disclosure to the police}

Policemen are often to be found around hospitals, particularly in accident and emergency departments. Normally the police have no special right to be told confidential information in the absence of a court order under the Police and Criminal Evidence Act (1984). ${ }^{1}$ There are a number of circumstances, however, in which disclosure is obligatory. ${ }^{2}$ These are circumstances in which other persons may be at risk or in which a serious crime may have been committed:

- Doctors are obliged under the Road Traffic Act (1988) to tell the police on request the name and address of a patient if he/she is suspected of being guilty of a driving offence.

- Doctors may be legally obliged to disclose information if there is reason to believe a serious crime has been committed and that patient or other persons may be in danger. "Serious crime" is not defined for medical purposes but would usually be violent in nature.

- Doctors are subject to the Prevention of Terrorism (Temporary Provisions) Act (1989) under which they are obliged to inform the police if they have any information relating to an act of terrorism or planned terrorism. This is particularly relevant in Northern Ireland.

A doctor should never make a formal statement in haste without due consultation with senior colleagues. Doctors should always bear in mind their ethical and professional duty of confidentiality and consider contacting their defence organisations if in doubt.

\section{Disclosure to lawyers}

Lawyers have no particular right to information when a crime is alleged to have been committed even when disclosure to the police is necessary. ${ }^{1}$ In due course, however, lawyers often request statements on behalf of patients. The defence organisations can offer advice about such medicolegal work.

\section{Disclosure to DVLA}

The General Medical Council's professional duties and responsibilities include provision for breaching confidentiality in extreme cases by informing the Driver and Vehicle Licensing Agency (DVLA) if a patient clearly unfit to drive continues to do so against advice. ${ }^{1}$ This would be exceptional.

\section{Death}

Doctors are legally obliged by the Births and Deaths Registration Act 1953 to report the death of a patient by accurate completion of a death certificate. ${ }^{2}$ If this is not possible, or if the cause of death is unnatural, the coroner may have to be informed. In other regards the duty of confidentiality to a patient continues after death. Consent to disclose passes to the executor of the estate of the deceased if there is a will, otherwise to the next-of-kin.

\section{Public health}

Notifiable diseases such as food poisoning, meningitis, tuberculosis, and so on must be reported to the public health department. ${ }^{2}$

Case 1

A man limps in with lacerations and abrasions giving an implausible story of an assault. $\mathrm{He}$ smells of alcohol. He has been sent to the $x$ ray department when the police arrive. They are looking for a driver who left the scene of a motor accident. Two people were killed in the other vehicle. What do you tell the policeman?

- You must tell the police that you have a patient with injuries consistent with a road traffic accident since there is reason to believe a serious motoring offence may have been committed here.
Submitted 24 May 2000 Accepted 2 August 2000 
Case 2

A young man has just died of bronchopneumonia after an urgent laparotomy. $\mathrm{He}$ was HIV positive and very cachectic. The organisms responsible for his pneumonia were typical of AIDS. The brother approaches you and begs you not to put AIDS down on the death certificate. What do you do?

- As HIV/AIDS was part of the causal chain you are obliged to register it as such and neither relatives nor patient (in form of advance directive) should deter you.

With thanks to Mr C Weir FRCS and Mr I Stirling FRCS, Craigavon Area Hospital.

1 General Medical Council. Confidentiality. London: GMC, 1995.

2 Medical Defence Union. Confidentiality. London: MDU, 1997.

\section{IMAGES IN MEDICINE}

\section{Adrenal myelolipoma}

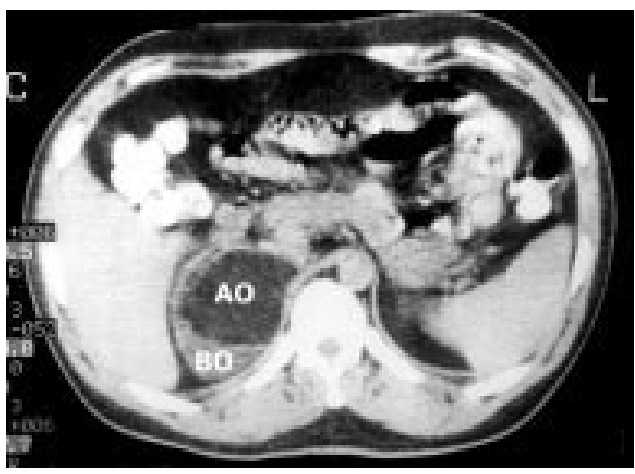

Figure 1 Contrast enhanced computed tomography of abdomen showing the soft tissue mass in right adrenal region.
A 26 year old man presented with two days of abdominal pain and vomiting. Ultrasonography of his abdomen revealed a right adrenal mass that was confirmed by contrast enhanced (oral and intravenous) computed tomography (CT), which showed a $20 \times 12 \times 6 \mathrm{~cm}$ well defined soft tissue mass in right adrenal region (see fig 1). There were two distinct areas of homogeneous attenuation containing fatty tissue component ( $\mathrm{AO}, \mathrm{CT}$ value -34 to $-54 \mathrm{HU}$ ) and soft tissue component $(\mathrm{BO}, \mathrm{CT}$ value +38 to $+44 \mathrm{HU}$ ) consistent with adrenal myelolipoma. No areas of haemorrhage or calcification were seen. He was subjected to surgery and tumour histopathology confirmed adrenal myelolipoma. 